\title{
Preparation of Diazabicyclo[4.3.0]nonene-Based Peptidomimetics
}

\author{
Craig A. Hutton ${ }^{\mathrm{a}, \mathrm{b}}$ and Paul A. Bartlett ${ }^{\mathrm{b}}$ \\ a School of Chemistry and Bio21 Molecular Science and Biotechnology Institute, The University of \\ Melbourne, VIC 3010, Australia, chutton@unimelb.edu.au \\ b Department of Chemistry, University of California, Berkeley, CA 94720-1460, USA
}

\section{Abstract}

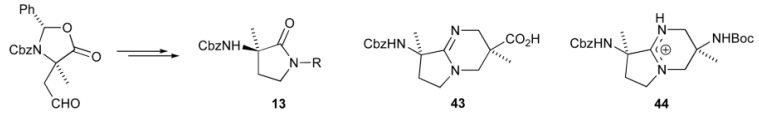

Several functionalized diazabicyclo[4.3.0]nonenes and other heterocycles have been prepared as potential peptidomimetic scaffolds. A novel and efficient method has been developed for the preparation of $N$-substituted $\gamma$-lactams 13. Preparation of amidine-containing 1,5-diazabicyclo[4.3.0] nonenes $\mathbf{4 3}$ and $\mathbf{4 4}$ has been achieved through $\mathrm{Hg}$-mediated cyclization of the precursor $N$ aminopropyl- $\gamma$-thiolactams and subsequent functional group manipulation. Bicycle $\mathbf{4 3}$ represents a novel scaffold for potential peptide turn mimetics, whereas $\mathbf{4 4}$ could potentially be employed as an $\alpha$-helix template attached to the C-terminus of peptides. These compounds are novel additions to the current range of small-molecule constrained peptidomimetics.

\section{Keywords}

Peptidomimetic; Diazabicyclo[4.3.0]nonene; Pyrrolo[1,2-a]pyrimidine; $\beta$-turn mimetic; $\alpha$-helix template

\section{Introduction}

Functionalized monocyclic and bicyclic compounds are highly useful scaffolds in the rational design and synthesis of peptidomimetics. ${ }^{1-5}$ These conformationally restricted heterocyclic frameworks have been used to generate mimics and templates of a variety of peptide secondary structural elements, particularly $\beta$-turns, ${ }^{6-17}$ but also $\gamma$-turns, ${ }^{18-20} \beta$-strands ${ }^{21-26}$ and $\alpha$ helices. ${ }^{27-31}$ Such scaffolds have been employed to constrain the backbone geometry and/or side-chain conformations of appended peptides to investigate the structural basis of peptideprotein and protein-protein interactions, and to develop potent and selective peptidomimetic therapeutic agents. Notable examples of constrained cyclic peptidomimetic scaffolds include the 6,5-fused azabicycloalkane-type $\beta$-turn mimetics, exemplified by the Nagai mimetic 1 $\left(\mathrm{X}=\mathrm{CH}_{2}, \mathrm{Y}=\mathrm{S}\right), 32$ 5,6-fused bicyclic hydrazones, e.g. 2,23,33 diketopiperazine $\beta$-turn mimetics $3,8,12,13,15$ the aza[4.3.0]bicyclononene and diproline-based $\alpha$-helix templates, $4^{27}$ and 5,28,29 respectively, medium-ring $\beta$-turn mimetics, e.g. 6,3,9,10,17 $\gamma$-lactamconstrained dipeptide surrogates 7,1,34 and the $\beta$-strand templates $8^{21,22}$ (Figure 1). 
We were interested in expanding the range of fused 5,6-bicyclic heterocycles available as peptidomimetic scaffolds. The diazabicyclo[4.3.0]nonene 9 represents such a novel peptidomimetic scaffold, in which incorporation of a carboxylate substituent $\left(\mathrm{R}_{2}=\mathrm{CO}_{2} \mathrm{H}\right)$ affords a dipeptide surrogate that could act as a turn mimetic. Alternatively, incorporation of an amino substituent $\left(\mathrm{R}_{2}=\mathrm{NH}_{2}\right)$ affords a potential $\alpha$-helix template related to the $N$-terminal $\alpha$-helix template 4 developed by Bartlett. ${ }^{27}$ Bicyclic amidine $\mathbf{9}\left(\mathrm{R}_{2}=\mathrm{NH}_{2}\right)$, in the protonated state, has a geometry matching that of $\mathbf{4}$ but with the three hydrogen-bond acceptor carbonyl groups replaced with donor $\mathrm{N}-\mathrm{H}$ groups, and represents a potential $\mathrm{C}$-terminal $\alpha$-helix template.

\section{Results and Discussion}

Retrosynthetic analysis of the bicyclic amidine 9 suggested that the bicycle could be formed by cyclodehydration of an $N$-(3-aminopropyl)- $\gamma$-lactam 10 (Scheme 1). ${ }^{35}$ While Freidinger ${ }^{1}$ has developed methods for the preparation of $\gamma$-lactam peptidomimetics, we envisaged a novel route to the $\gamma$-lactam 10 through reductive amination of an aspartate-semi aldehyde derivative 11 with amine 12, followed by cyclization. Alternatively, 10 could be accessed by Michaeltype addition of $\gamma$-lactam 13 to substituted acrylate 14. With the $\gamma$-lactam 13 accessible from 11 through a similar reductive amination-cyclization process, and the amine $\mathbf{1 2}$ accessible from acrylate 14, the required starting materials for this strategy are the aldehyde $\mathbf{1 1}$ and acrylate 14. We chose to incorporate $\alpha$-methyl substituents $\left(9 R_{1}, R_{3}=M e\right)$ for additional conformational constraint. Accordingly, our synthesis was initiated with oxazolidinone 16, prepared via condensation of Cbz-L-alanine 15 with benzaldehyde dimethyl acetal according to Shrader's modification ${ }^{36}$ of the procedure of Karady et al. ${ }^{37}$ Alkylation of the oxazolidinone 16 was achieved in $91 \%$ yield by treatment with lithium hexamethyldisilazide followed by addition of allyl iodide (Scheme 2). Only the $(2 S, 4 S)$ )-isomer was detected by ${ }^{1} \mathrm{H}$ NMR spectroscopy, indicating that the reaction had proceeded to give the allyloxazolidinone $\mathbf{1 7}$ in $>95: 5$ diastereomeric ratio. Ozonolysis of the allyloxazolidinone 17 gave the requisite aldehyde $\mathbf{1 8}$ in $82 \%$ yield (Scheme 2 ).

\section{A. Preparation of $\mathrm{y}$-Lactam}

A reductive amination/cyclization strategy from $\mathbf{1 8}$ was investigated as a route to $\gamma$-lactam scaffolds. Treatment of the aldehyde $\mathbf{1 8}$ with ammonium chloride and sodium cyanoborohydride gave the $\gamma$-lactam $\mathbf{2 0}$ directly, presumably via cyclization of intermediate amine 19 with concomitant release of benzaldehyde (Scheme 3). However, the $\gamma$-lactam 20 was produced in low yield, with the $N$-benzyl lactam 21 isolated as the major product. The $\mathrm{N}$ benzyl lactam 21 presumably forms by reductive amination of the benzaldehyde byproduct generating benzylamine, which then undergoes reductive amination/cyclization with aldehyde 18. An efficient preparation of the lactam 20 was ultimately achieved using $p$-anisidine as the amine partner in the reductive amination of 18. Under these conditions PMP-lactam 22 was produced in $90 \%$ yield, which upon treatment with ceric ammonium nitrate gave $\gamma$-lactam 20 in good yield (Scheme 4).

\section{B. Synthesis of diazabicyclo[4.3.0]nonene ring system}

Extension of the reductive amination/cyclization methodology was then investigated using functionalized diamines as a route toward the diazabicyclo[4.3.0]nonene ring system. Treatment of the aldehyde $\mathbf{1 8}$ with Boc-diaminopropane $\mathbf{2 3}$ under reductive amination conditions gave the bicyclic compound $\mathbf{2 4}$ in $52 \%$ yield, as a 1:1 ratio of diastereomers (Scheme 5). Formation of the bicyclic compound $\mathbf{2 4}$ presumably occurs via the initially formed iminium species 25, with two cyclization events and elimination of benzaldehyde yielding the bicyclic product 24. 
It was anticipated that replacement of Boc-protected diamine $\mathbf{2 3}$ with the corresponding phthaloyl-protected compound $\mathbf{2 6}$ would prevent intramolecular attack of the intermediate iminium species, thereby preventing formation of the bicyclic compound. Accordingly, treatment of the aldehyde 18 with 1.5 equivalents of the phthaloyl-protected diaminopropane 26 in the presence of sodium cyanoborohydride gave the phthalimidopropyl- $\gamma$-lactam 27 in $\mathbf{7 5 \%}$ yield (Scheme 6). A slight excess of amine $\mathbf{2 6}$ is required for optimum yields of $\mathbf{2 7}$, as some of the amine undergoes reductive amination with the benzaldehyde byproduct formed concurrently with production of the $\gamma$-lactam 27 .

Removal of the phthaloyl group from $\mathbf{2 7}$ was effected by treatment with hydrazine hydrate in ethanol, to generate the amine 28. Subsequent attempts to cyclodehydrate the aminopropyl- $\gamma$ lactam 28 to the bicyclic amidine $\mathbf{2 9}$, including refluxing in high boiling point solvents with catalytic acid, and via the corresponding $O$-silyl- and $O$-alkyl-imidates, were unsuccessful.

35 Accordingly, $\gamma$-lactam 27 was converted to the corresponding thiolactam 30 by treatment with Lawesson's reagent. ${ }^{38}$ The phthalimidopropyl thiolactam $\mathbf{3 0}$ was isolated in moderate yield, together with varying amounts of a byproduct, presumed to be the dithio-compound 31 (Scheme 7). Various conditions were employed in an attempt to improve the yield of the thiolactam 30, however variation of the amount of Lawesson's reagent and the reaction time did not result in significant improvements in the yield of $\mathbf{3 0}$ (optimum $40 \%$, with $20 \%$ unreacted starting material). Treatment of the thiolactam $\mathbf{3 0}$ with hydrazine hydrate gave the free amine 32 in $77 \%$ yield. The amine was then treated with mercuric chloride in $\mathrm{THF}^{34,39}$ to give the bicyclic amidine $\mathbf{2 9}$ in $67 \%$ yield. The amidine $\mathbf{2 9}$ was found to be unstable as its free base, and was therefore purified and stored as its trifluoroacetate salt.

\section{Synthesis of functionalized diazabicyclo[4.3.0]nonene ring system}

With a method for preparing the alanine-derived diazabicyclo[4.3.0]nonene derivative 29 in hand, preparation of the carboxylate-functionalized bicycle 41via the corresponding carboxylate-functionalized phthalimidopropyl- $\gamma$-lactam 37 was investigated. Initial attempts to prepare $\mathbf{3 7}$ by Michael-type addition of $\gamma$-lactam $\mathbf{2 0}$ to phthalimidomethacrylate $\mathbf{3 4}$ were unsuccessful. Hence, the reductive amination-cyclization route was followed as for the preparation of amidine $\mathbf{2 9}$, which necessitated preparation of amine $\mathbf{3 6}$. Phthalimidomethylacrylate $\mathbf{3 4}$ was prepared from the corresponding bromide $\mathbf{3 3}$, then was treated with one equivalent of benzylamine to give the amine 35 in $57 \%$ yield (76\% based on recovered starting material) (Scheme 8). Use of excess benzylamine in attempts to increase the yield of the amine $\mathbf{3 5}$ only resulted in the formation of increasing amounts of $\mathrm{N}$ -

benzylphthalimide, presumably via transimidation of either the acrylate $\mathbf{3 4}$ or the amine $\mathbf{3 5}$ with excess benzylamine.

Removal of the benzyl group from the amine $\mathbf{3 5}$ was initially attempted by hydrogenation in the presence of Pearlman's catalyst, however, the procedure was not reproducible and normally resulted in the recovery of the benzyl-protected amine 35. Alternative debenzylation conditions were therefore investigated, and ultimately treatment of the $\mathrm{N}$-benzylamine 35 with $\mathrm{N}$ -

bromosuccinimide (NBS) or bromine in methylene chloride/water was found to give the amine as its hydrobromide salt 36, in high yield (Scheme 8). ${ }^{40}$ While $N$-debenzylation under these conditions has been employed sporadically, the use of this procedure is most common with $N$-benzylamides, ${ }^{41,42}$ with the $N$-debenzylation of amines ${ }^{40,43}$ - particularly secondary amines ${ }^{44}$ - being rare. The use of NBS and bromine were equally effective, with the use of bromine being the method of choice on large scale as removal of the succinimide byproduct is avoided.

Synthesis of the bicyclic amidine $\mathbf{4 1}$ then followed the protocol outlined in Scheme 7 for the synthesis of the model compound 29. Reductive amination of the aldehyde $\mathbf{1 8}$ with the amine hydrobromide salt $\mathbf{3 6}$ gave the $\gamma$-lactam 37 in $71 \%$ yield, as a 1:1 ratio of diastereomers. The 
diastereomers were separable by chromatography and independently characterized, but in subsequent reactions a 1:1 mixture of the diastereomers of $\mathbf{3 7}$ was employed. As with the conversion of aldehyde $\mathbf{1 8}$ and amine $\mathbf{2 6}$ to give $\gamma$-lactam $\mathbf{2 7}$ (Scheme 6), conversion of $\mathbf{1 8}$ and amine $\mathbf{3 6}$ to give $\gamma$-lactam $\mathbf{3 7}$ required an excess of the amine due to the competing reductive amination with the benzaldehyde byproduct (Scheme 9). It should be noted, however, that in this case this secondary reductive amination process converts excess amine $\mathbf{3 6}$ into its corresponding $N$-benzyl derivative $\mathbf{3 5}$, which is the immediate precursor of the amine $\mathbf{3 6}$. The use of 1.5 equivalents of amine $\mathbf{3 6}$ in the reductive amination of $\mathbf{1 8}$ gave, in addition to $81 \%$ yield of the desired lactam 37, the $N$-benzylamine 35 in $24 \%$ yield (72\% recovery of excess amine, which can be recycled back to the amine $\mathbf{3 6}$ thereby improving the overall efficiency of the process).

Formation of the thiolactam $\mathbf{3 8}$ was performed by treatment of the $\gamma$-lactam $\mathbf{3 7}$ with 0.55 equivalents of Lawesson's reagent in refluxing toluene (Scheme 9). The thiolactam $\mathbf{3 8}$ was isolated in 56\% yield, and the dithio compound 39 in $10 \%$ yield. The yield of the thiolactam 38 was higher than for the corresponding reaction in the model series $(\mathbf{2 7} \rightarrow \mathbf{3 0})$, presumably because the methoxycarbonyl group sterically shields the phthaloyl group, thereby slowing formation of the dithio compound $\mathbf{3 9}$.

Initial attempts to remove the phthaloyl group of $\mathbf{3 8}$ by hydrazinolysis with hydrazine hydrate in refluxing ethanol were unsuccessful, and the starting material was recovered. After experimentation with various methods it was found that treatment of the thiolactam $\mathbf{3 8}$ with anhydrous hydrazine in methanol gave a satisfactory yield of the free amine $\mathbf{4 0 .}$

With the functionalized aminopropyl-thiolactam $\mathbf{4 0}$ in hand, synthesis of the bicylic amidine was investigated. Treatment of the thiolactam $\mathbf{4 0}$ with mercuric chloride in refluxing THF proceeded slowly, with some starting material still remaining after two days. Dioxane was therefore substituted for THF, and the corresponding reaction using dioxane as solvent was found to be complete in 24 hours (Scheme 9). Purification of the amidine $\mathbf{4 1}$ proved troublesome, with the solvent system used in chromatographic purification of the model amidine $29\left(\mathrm{CHCl}_{3} / \mathrm{MeOH} / \mathrm{TFA}\right)$ proving ineffective. The dilemma was solved through the use of either reverse-phase column chromatography, or normal phase silica chromatography eluting with $\mathrm{CH}_{2} \mathrm{Cl}_{2} / \mathrm{MeOH} /$ isopropylamine, with the amidine $\mathbf{4 1}$ isolated in $62 \%$ yield as a 1:1 mixture of diastereomers (Scheme 9).

Alkylation of the amidine $\mathbf{4 1}$ adjacent to the ester moiety was then investigated in order to introduce further conformational restraint to the bicyclic scaffold. ${ }^{27}$ Treatment of the amidine 41 with 5.5 equivalents of LHMDS and 3.5 equivalents of methyl iodide gave a moderate yield of the alkylated compound $\mathbf{4 2}$ (Scheme 10). Only one diastereomer was detectable by ${ }^{1} \mathrm{H}$ NMR spectroscopy of the crude product, indicating that the reaction proceeds stereoselectively to give $\mathbf{4 2}$ in > 95:5 diastereomeric ratio. While the stereochemical identity of the product was not established definitively, it is presumed to arise from approach of the electrophile from the side opposite to the bulky, pseudo-axial CbzNH-group. This is also in accord with the reported $\alpha$-methylations of cyclohexane carboxylate esters in which the methyl groups are installed in a cis-manner in equatorial positions. 45

Alkaline hydrolysis of ester $\mathbf{4 2}$ gave the corresponding acid $\mathbf{4 3}$ in quantitative yield. Acid $\mathbf{4 3}$ was then transformed through a Curtius rearrangement to the corresponding Boc-protected amine $\mathbf{4 4}$, isolated in good yield as the diphenylphosphate salt.

\section{Conclusion}

Several functionalized diazabicyclo[4.3.0]nonenes and other heterocycles have been prepared as peptidomimetic scaffolds. A novel and efficient method has been developed for the 
preparation $N$-substituted $\gamma$-lactams, which have previously been utilized as constrained dipeptide surrogates. A rapid assembly of the 1,5-diazabicyclo[4.3.0]nonan-9-one ring system 24 has been achieved through a one-pot reductive amination-tandem cyclization process. Preparation of amidine-containing 1,5-diazabicyclo[4.3.0]nonenes 29 and $\mathbf{4 1 - 4 4}$ has been achieved through $\mathrm{Hg}$-mediated cyclization of the precursor $\mathrm{N}$-aminopropyl- $\gamma$-thiolactams and subsequent functional group manipulation. C3-Carboxylate-functionalized compound $\mathbf{4 3}$, containing a fused 5,6-bicyclic ring system and the combination of a protected amino group and carboxylic acid, represents a novel scaffold for potential peptide turn mimetics. C3-Aminofunctionalized compound $\mathbf{4 4}$, containing a protonated amidine and two differentially-protected amino groups, could potentially be employed as an $\alpha$-helix template attached to the C-terminus of peptides. The three $\mathrm{N}-\mathrm{H}$ hydrogen bond donors of $\mathbf{4 4}$ are positioned in an analogous arrangement to the three carbonyl group hydrogen bond acceptors of the $\mathrm{N}$-terminal template $\mathbf{4}$, and therefore mimics the hydrogen-bonding pattern of the first turn at the $\mathrm{C}$-terminus of an $\alpha$-helix. These compounds are novel additions to the current range of small-molecule constrained peptidomimetics.

\section{Experimental Section}

General procedures are available in the Supporting Information.

\section{(2S,4S)-3-Benzyloxycarbonyl-4-methyl-2-phenyl-4-(prop-2-enyl)oxazolidin-5-one 17}

A solution of the oxazolidinone $\mathbf{1 6}^{36}(15.0 \mathrm{~g}, 48.2 \mathrm{mmol})$ in dry THF $(80 \mathrm{~mL})$, under an atmosphere of argon, was cooled to $-78^{\circ} \mathrm{C}$. A solution of lithium hexamethyldisilazide in THF $(1.0 \mathrm{M}, 63 \mathrm{~mL})$ was added slowly and the mixture was stirred for $15 \mathrm{~min}$. Allyl iodide $(6.3 \mathrm{~mL}$, $68.9 \mathrm{mmol}$ ), which had been passed through a short column of alumina, was then added and the mixture was stirred at $-78^{\circ} \mathrm{C}$ for $3 \mathrm{~h}$. The mixture was allowed to warm to room temperature and was stirred for a further $18 \mathrm{~h}$. The mixture was diluted with ether $(250 \mathrm{~mL})$, and was quenched by the addition of sat. $\mathrm{NH}_{4} \mathrm{Cl}(250 \mathrm{~mL})$. The organic layer was separated and was washed with sat. $\mathrm{NH}_{4} \mathrm{Cl}$. The combined aqueous layers were extracted with ether, then the organic layers were combined, dried, and the solvent was removed under reduced pressure. The residue was purified by chromatography on silica to give the oxazolidinone $\mathbf{1 7}$ (15.45 g, $91 \%)$ as a clear, viscous oil. ${ }^{1} \mathrm{H}$ NMR $\left(400 \mathrm{MHz}, \mathrm{CDCl}_{3}\right)$ (major rotamer) $\underline{\delta} 1.81(3 \mathrm{H}, \mathrm{s}), 2.54$ $(1 \mathrm{H}, \mathrm{dd}, J 6.313 .5), 3.27(1 \mathrm{H}, \mathrm{dd}, J 8.913 .5), 4.96(2 \mathrm{H}, \mathrm{m}), 5.16(2 \mathrm{H}, \mathrm{m}), 5.67(1 \mathrm{H}, \mathrm{m}), 6.28$ $(1 \mathrm{H}, \mathrm{s}, \mathrm{NH}), 6.87(1 \mathrm{H}, \mathrm{m}), 7.18-7.41(9 \mathrm{H}, \mathrm{m})$; (minor rotamer) $\delta 1.72(3 \mathrm{H}, \mathrm{s}), 2.54(1 \mathrm{H}, \mathrm{dd}$, $J$ 6.313 .5$), 2.92(1 \mathrm{H}, \mathrm{dd}, J 8.513 .5), 4.96(2 \mathrm{H}, \mathrm{m}), 5.16(2 \mathrm{H}, \mathrm{m}), 5.60(1 \mathrm{H}, \mathrm{m}), 6.34(1 \mathrm{H}, \mathrm{s}$, $\mathrm{NH}), 6.87(1 \mathrm{H}, \mathrm{m}, \mathrm{ArH}), 7.18-7.41(9 \mathrm{H}, \mathrm{m}, \mathrm{ArH}) .{ }^{13} \mathrm{C} \mathrm{NMR}\left(100 \mathrm{MHz}, \mathrm{CDCl}_{3}\right)$ 8 23.6, 39.4, 63.1, 67.2, 89.4, 121.3, 126.8, 127.8, 128.1, 128.3, 128.7, 129.8, 130.9, 135.2, 137.0, 151.7, 174.1. MS (FAB) $\mathrm{m} / \mathrm{z} 352\left(100 \%, \mathrm{M}+\mathrm{H}^{+}\right)$.

\section{(2S,4S)-3-Benzyloxycarbonyl-4-methyl-4-(2-oxoethyl)-2-phenyloxazolidin-5-one 18}

A solution of the allyloxazolidinone $17(7.8 \mathrm{~g}, 22.2 \mathrm{mmol})$ in methylene chloride (200 mL) was cooled to $-78^{\circ} \mathrm{C}$, then ozone was bubbled through the solution until it turned blue (ca. 45 min). Oxygen was bubbled through the solution until it became colourless. Dimethyl sulfide $\left(33 \mathrm{~mL}\right.$ ) was added, and the solution was stirred at $-78^{\circ} \mathrm{C}$ for $30 \mathrm{~min}$. The solution was allowed to warm to room temperature, then the solvent was removed under reduced pressure. The residue was purified by chromatography on silica and was recrystallized from hexanes/ethyl acetate to give the aldehyde $18(6.44 \mathrm{~g}, 82 \%)$ as colourless prisms. M.p. $109-110{ }^{\circ} \mathrm{C} .{ }^{1} \mathrm{H}$ NMR $\left(400 \mathrm{MHz}, \mathrm{CDCl}_{3}\right)$ (major rotamer) $\delta 1.76(3 \mathrm{H}, \mathrm{s}), 3.07(1 \mathrm{H}, \mathrm{d}, J=15.5 \mathrm{~Hz}), 4.04(1 \mathrm{H}, \mathrm{d}, J=$ $15.5 \mathrm{~Hz}), 4.84(1 \mathrm{H}, \mathrm{d}, J=9.9 \mathrm{~Hz}), 4.97(1 \mathrm{H}, \mathrm{d}, J=9.9 \mathrm{~Hz}), 6.57(1 \mathrm{H}, \mathrm{s}), 6.79(1 \mathrm{H}, \mathrm{m}), 7.16-$ $7.48(9 \mathrm{H}, \mathrm{m}), 9.92(1 \mathrm{H}, \mathrm{s}) .{ }^{13} \mathrm{C} \mathrm{NMR}\left(100 \mathrm{MHz}, \mathrm{CDCl}_{3}\right)$ (major rotamer) $\delta 24.4,48.4,57.8$, $67.3,89.9,127.1,127.5,128.0,128.3,128.6,129.8,135.1,136.6,151.8,173.6,198.6 . \mathrm{MS}$ 
(FAB) $\mathrm{m} / z .354\left(100 \%, \mathrm{M}+\mathrm{H}^{+}\right)$. Anal. Calcd for $\mathrm{C}_{20} \mathrm{H}_{19} \mathrm{NO}_{5}$ : C 68.0, $\mathrm{H}$ 5.4, $\mathrm{N}$ 4.0. Found: $\mathrm{C}$ 68.0, H 5.5, N 4.1.

\section{(3R)-3-Benzyloxycarbonylamino-3-methyl-1-(3-phthalimidopropyl)pyrrolidin-2-one 27}

To a solution of the aldehyde $\mathbf{1 8}(1.0 \mathrm{~g}, 2.83 \mathrm{mmol})$ and the amine salt $\mathbf{2 6}(1.35 \mathrm{~g}, 4.25 \mathrm{mmol})$ in methanol $(25 \mathrm{~mL})$ was added $\mathrm{NaCNBH}_{3}(267 \mathrm{mg}, 4.25 \mathrm{mmol})$ and $\mathrm{NaOAc}(100 \mathrm{mg})$. Acetic acid was added dropwise to lower the $\mathrm{pH}$ to 6.0. The solution was then stirred at room temperature for $36 \mathrm{~h}$, then the solvent was removed under reduced pressure. The residue was taken up in ether/methylene chloride (5:1) and was washed with water, then dilute $\mathrm{HCl}$, then with water. The organic phase was dried and the solvent was removed under reduced pressure. Purification of the residue by chromatography on silica gave the lactam $27(0.92 \mathrm{~g}, 75 \%)$ as a colorless oil, which solidified after storage at $-20^{\circ} \mathrm{C}$. M.p. $73-75^{\circ} \mathrm{C} .{ }^{1} \mathrm{H}$ NMR $(400 \mathrm{MHz}$, $\left.\mathrm{CDCl}_{3}\right) \delta 1.41(3 \mathrm{H}, \mathrm{s}), 1.93(1 \mathrm{H}, \mathrm{m}), 1.97(1 \mathrm{H}, \mathrm{m}), 2.35(1 \mathrm{H}, \mathrm{m}), 2.45(1 \mathrm{H}, \mathrm{m}), 3.32(1 \mathrm{H}, \mathrm{m})$, $3.39(2 \mathrm{H}, \mathrm{m}), 3.48(1 \mathrm{H}, \mathrm{m}), 3.66(1 \mathrm{H}, \mathrm{m}), 3.71(1 \mathrm{H}, \mathrm{m}), 5.04(1 \mathrm{H}, \mathrm{d}, J=12.2 \mathrm{~Hz}), 5.09(1 \mathrm{H}$, $\mathrm{d}, J=12.2 \mathrm{~Hz}), 5.42(1 \mathrm{H}, \mathrm{br} \mathrm{s}), 7.32(5 \mathrm{H}, \mathrm{m}), 7.71(2 \mathrm{H}, \mathrm{m}), 7.83(2 \mathrm{H}, \mathrm{m}) .{ }^{13} \mathrm{C}$ NMR $(100$ $\left.\mathrm{MHz}, \mathrm{CDCl}_{3}\right) \delta 22.2,25.9,32.7,35.3,40.5,43.4,57.8,66.4,123.1,127.8,127.9,128.3,132.0$, 133.9, 136.3, 154.9, 168.0, 174.5. Anal. Calcd for $\mathrm{C}_{24} \mathrm{H}_{25} \mathrm{~N}_{3} \mathrm{O}_{5}$ : C 66.2, H 5.8, N 9.7. Found: C 66.5, H 6.0, N 9.9.

\section{(3R)-3-Benzyloxycarbonylamino-3-methyl-1-(3-phthalimidopropyl)pyrrolidin-2-thione 30}

To a solution of the lactam $27(400 \mathrm{mg}, 0.92 \mathrm{mmol})$ in dry toleune $(5 \mathrm{~mL})$ was added Lawesson's reagent $(124 \mathrm{mg}, 0.31 \mathrm{mmol})$, and the mixture was heated at reflux for $2 \mathrm{~h}$. The mixture was cooled and the solvent was removed under reduced pressure. The residue was chromatographed on silica to give the dithio-compound $\mathbf{3 1}(28 \mathrm{mg}, 7 \%)$ and the thiolactam $\mathbf{3 0}(165 \mathrm{mg}, 40 \%)$ as a white solid. M.p. $55-57{ }^{\circ} \mathrm{C} .{ }^{1} \mathrm{H}$ NMR $\left(400 \mathrm{MHz}, \mathrm{CDCl}_{3}\right) \delta 1.45(3 \mathrm{H}, \mathrm{s}), 2.07(2 \mathrm{H}, \mathrm{m})$, $2.42(1 \mathrm{H}, \mathrm{m}), 2.61(1 \mathrm{H}, \mathrm{m}), 3.70(4 \mathrm{H}, \mathrm{m}), 3.74(1 \mathrm{H}, \mathrm{m}), 3.97(1 \mathrm{H}, \mathrm{m}), 5.07(2 \mathrm{H}, \mathrm{s}), 6.00(1 \mathrm{H}$, s), 7.28-7.35 (5H, m), $7.72(2 \mathrm{H}, \mathrm{m}), 7.83(2 \mathrm{H}, \mathrm{m}) .{ }^{13} \mathrm{C} \mathrm{NMR}\left(100 \mathrm{MHz}, \mathrm{CDCl}_{3}\right) \delta 24.6,25.3$, 34.2, 35.2, 45.9, 51.4, 66.3, 66.6, 123.2, 127.8, 127.9, 128.4, 131.9, 134.0, 136.4, 154.7, 168.1, 204.1. Anal. Calcd for $\mathrm{C}_{24} \mathrm{H}_{25} \mathrm{~N}_{3} \mathrm{O}_{4} \mathrm{~S}$ : C 63.8, H 5.6, N 9.3. Found: C 64.1,H 5.8, N 9.5.

\section{(3R)-1-(3-Aminopropyl)-3-benzyloxycarbonylamino-3-methylpyrrolidin-2-thione 32}

To a solution of the thiolactam $30(1.1 \mathrm{~g}, 2.4 \mathrm{mmol})$ in ethanol $(20 \mathrm{~mL})$ was added a solution of hydrazine hydrate in ethanol $(2 \mathrm{M}, 2.4 \mathrm{~mL})$. The solution was heated at reflux for $2.5 \mathrm{~h}$, then was allowed to cool and the solvent was removed under reduced pressure. The residue was suspended in dilute $\mathrm{HCl}(30 \mathrm{~mL})$, and the mixture was heated at $50^{\circ}$ for $15 \mathrm{~min}$. The mixture was cooled and the precipitate was removed by filtration. The filtrate was washed with methylene chloride, then the aqueous layer was made basic $(\mathrm{pH}>11)$ by the addition of $6 \mathrm{~N}$ $\mathrm{NaOH}$. The solution was extracted twice with ethyl actetate, then the combined organic phases were dried and the solvent was removed under reduced pressure, to give the amine 32 (605 $\mathrm{mg}, 77 \%)$ as a pale yellow oil. ${ }^{1} \mathrm{H}$ NMR $\left(400 \mathrm{MHz}, \mathrm{CDCl}_{3}\right) \delta 1.41(3 \mathrm{H}, \mathrm{s}), 1.67(2 \mathrm{H}, \mathrm{br} \mathrm{s})$, $1.77(2 \mathrm{H}, \mathrm{m}), 2.41(1 \mathrm{H}, \mathrm{m}), 2.49(1 \mathrm{H}, \mathrm{m}), 2.67(2 \mathrm{H}, \mathrm{m}), 3.56(1 \mathrm{H}, \mathrm{m}), 3.63(1 \mathrm{H}, \mathrm{m}), 3.78(1 \mathrm{H}$, m), $3.86(1 \mathrm{H}, \mathrm{m}), 5.07(2 \mathrm{H}, \mathrm{s}), 6.21(1 \mathrm{H}, \mathrm{br} \mathrm{s}), 7.31(\mathrm{~s}, 5 \mathrm{H}) .{ }^{13} \mathrm{C} \mathrm{NMR}\left(100 \mathrm{MHz}, \mathrm{CDCl}_{3}\right) \delta$ $24.9,27.9,33.8,37.9,45.7,51.4,66.4,66.8,127.9,128.0,128.4,136.3,154.8,204.0 . \mathrm{MS}$ (FAB) $m / z, 322\left(100 \%, \mathrm{M}+\mathrm{H}^{+}\right)$.

\section{(S)-7-Amino-7-methyl-1,5-diazabicyclo[4.3.0]non-5-ene 29}

To a solution of the amine $32(600 \mathrm{mg}, 1.87 \mathrm{mmol})$ in dry THF $(10 \mathrm{~mL})$ was added $\mathrm{HgCl}_{2}$ (760 $\mathrm{mg}, 2.80 \mathrm{mmol})$. The mixture was heated at reflux for $18 \mathrm{~h}$, then the mixture was filtered and the filtrate was evaporated under reduced pressure. The residue was purified by chromatography on silica, eluting with $\mathrm{CHCl}_{3} / \mathrm{MeOH} / \mathrm{TFA}$ (70:30:1) to give the bicyclic amidine 29 as its trifluoroacetate salt $(502 \mathrm{mg}, 67 \%)$ as a clear oil. ${ }^{1} \mathrm{H}$ NMR $(400 \mathrm{MHz}$, 
$\left.\mathrm{CDCl}_{3}\right) \delta 1.64(3 \mathrm{H}, \mathrm{s}), 2.02(2 \mathrm{H}, \mathrm{m}), 2.09(1 \mathrm{H}, \mathrm{m}), 2.75(1 \mathrm{H}, \mathrm{m}) .3 .39(2 \mathrm{H}, \mathrm{m}), 3.44(2 \mathrm{H}, \mathrm{m})$, $3.63(1 \mathrm{H}, \mathrm{m}), 3.80(1 \mathrm{H}, \mathrm{m}), 5.02(1 \mathrm{H}, \mathrm{d}, J=12.5 \mathrm{~Hz}), 5.10(1 \mathrm{H}, \mathrm{d}, J=12.5 \mathrm{~Hz}), 7.32(5 \mathrm{H}$, m). ${ }^{13} \mathrm{C} \mathrm{NMR}\left(100 \mathrm{MHz}, \mathrm{CDCl}_{3}\right) \delta 18.4,24.7,32.8,38.0,43.3,51.2,61.3,67.0,127.6,128.0$, 128.4, 136.2, 156.8, 167.3. MS (FAB) $m / z 288\left(100 \%, \mathrm{M}+\mathrm{H}^{+}\right.$). HRMS (FAB) $m / z .288 .1704$, $\mathrm{C}_{16} \mathrm{H}_{22} \mathrm{~N}_{3} \mathrm{O}_{2}$ requires 288.1712 .

\section{Methyl 3-Benzylamino-2-(phthalimidomethyl)propanoate 35}

To a solution of the acrylate $34^{46}(5.0 \mathrm{~g}, 20.4 \mathrm{mmol})$ in chloroform $(25 \mathrm{~mL})$ was added benzylamine $(2.2 \mathrm{~g}, 20.5 \mathrm{mmol})$. The solution was refluxed for $2 \mathrm{~d}$, then was cooled and the solvent removed under reduced pressure. Purification of the residue by chromatography on silica recovered some acrylate $\mathbf{3 4}(1.23 \mathrm{~g}, 25 \%)$ and gave the amine $\mathbf{3 5}(4.42 \mathrm{~g}, 57 \%)$ as a white solid. M.p. 82-83 ${ }^{\circ}$ C. IR v 3470, 3326, 1773, 1734, 1715, 1398, 1367, $1201 \mathrm{~cm}^{-1} .{ }^{1} \mathrm{H}$ NMR $\left(400 \mathrm{MHz}, \mathrm{CDCl}_{3}\right) \delta 1.81(1 \mathrm{H}$, br s), $2.83(1 \mathrm{H}, \mathrm{dd}, J=5.7,12.3 \mathrm{~Hz}), 2.89(1 \mathrm{H}, \mathrm{dd}, J=6.7$, $12.3 \mathrm{~Hz}), 3.03(1 \mathrm{H}, \mathrm{m}), 3.67(3 \mathrm{H}, \mathrm{s}), 3.77(2 \mathrm{H}, \mathrm{s}), 3.97(1 \mathrm{H}, \mathrm{dd}, J=6.7,14.0 \mathrm{~Hz}), 4.00(1 \mathrm{H}$, $\mathrm{dd}, J=7.0,14.0 \mathrm{~Hz}), 7.20(1 \mathrm{H}, \mathrm{m}), 7.27(4 \mathrm{H}, \mathrm{m}), 7.71(2 \mathrm{H}, \mathrm{m}), 7.83(2 \mathrm{H}, \mathrm{m}) .{ }^{13} \mathrm{C} \mathrm{NMR}(100$ $\left.\mathrm{MHz}_{2} \mathrm{CDC1}_{3}\right) \delta 37.3,44.5,47.7,51.9,53.6,123.3,126.8,128.0,128.2,131.9,133.4,140.0$, 168.1, 173.0. MS (FAB) $m / z 353\left(100 \%, \mathrm{M}+\mathrm{H}^{+}\right)$. Anal. Calcd for $\mathrm{C}_{20} \mathrm{H}_{20} \mathrm{~N}_{2} \mathrm{O}_{4}$ : C 68.2, H 5.7, N 8.0. Found: C 68.1, H 5.9, N 7.8.

\section{Methyl 3-Amino-2-(phthalimidomethyl)propanoate Hydrobromide 36}

To a solution of the amine $35(23.0 \mathrm{~g}, 65.3 \mathrm{mmol})$ in methylene chloride $(300 \mathrm{~mL})$ was added water $(40 \mathrm{~mL})$ and the mixture was stirred vigorously. Bromine $(11.0 \mathrm{~g}, 68.8 \mathrm{mmol})$ in methylene chloride $(60 \mathrm{~mL})$ was added dropwise over $c a .30 \mathrm{~min}$., after which vigorous stirring was continued for $4 \mathrm{~h}$. The mixture was extracted with water $(300 \mathrm{~mL})$, and the aqueous layer was lyophilized to give the amine salt $36(20.4 \mathrm{~g}, 91 \%)$ as a white powder. Recrystallization from ether/methanol gave the amine salt 36 as fine crystals. M.p. $184-186{ }^{\circ} \mathrm{C}$ (decomp.). ${ }^{1} \mathrm{H}$ NMR (400 MHz, D $2 \mathrm{O}) \delta 3.33(2 \mathrm{H}, \mathrm{m}), 3.42(1 \mathrm{H}, \mathrm{m}), 3.78(3 \mathrm{H}, \mathrm{s}), 4.00(1 \mathrm{H}, \mathrm{dd}, J=5.414 .7$ $\mathrm{Hz}), 4.07(1 \mathrm{H}, \mathrm{dd}, J=6.314 .7 \mathrm{~Hz}), 7.83(4 \mathrm{H}, \mathrm{s}) .{ }^{13} \mathrm{C} \mathrm{NMR}\left(100 \mathrm{MHz}, \mathrm{D}_{2} \mathrm{O}\right) \delta 37.0,38.0$, 42.1, 53.2, 123.6, 130.8, 135.1, 170.0, 172.6. MS (FAB) $\mathrm{m} / \mathrm{z} 263\left(100 \%, \mathrm{M}+\mathrm{H}^{+}\right)$. Anal. Calcd for $\mathrm{C}_{13} \mathrm{H}_{15} \mathrm{BrN}_{2} \mathrm{O}_{2}$ : C 45.5, H 4.4, N 8.2. Found: C 45.7, H 4.5, N 8.0.

\section{(3R)-3-Benzyloxycarbonylamino-3-methyl-1-((2RS)-2-methoxycarbonyl-3-phthalimido)- propyl)pyrrolidin-2-one 37}

To a solution of the aldehyde $18(13.7 \mathrm{~g}, 38.8 \mathrm{mmol})$ in methanol $(250 \mathrm{~mL})$ was added the amine salt 36 (20.0 g, $58.3 \mathrm{mmol})$ and sodium cyanoborohydride $(3.7 \mathrm{~g}, 58.9 \mathrm{mmol})$. The solution was stirred at room temperature for $3 \mathrm{~d}$, with acetic acid being added to keep $\mathrm{pH} \sim 6$ (ca. $2 \mathrm{~mL}$ ). The solvent was removed under reduced pressure, the residue was partitioned between ethyl acetate and water, and the aqueous phase was re-extracted with ethyl acetate. The combined organic phases were dried, and the solvent was removed under reduced pressure. The residue was subject to chromatography on silica, eluting with 3:1 ethyl acetate/hexanes, to give the $N$-benzylamine $35(4.85 \mathrm{~g}, 24 \%)$, and the lactam $37(15.5 \mathrm{~g}, 81 \%)$ as a foam, as a 1:1 mixture of diastereomers. Further chromatography enabled isolation of pure samples of each of the diastereomers of $\mathbf{3 7}$. The first eluting diastereomer was obtained as a glassy solid: M.p. 66-71 ${ }^{\circ} \mathrm{C}$. IR v 3420, 3403, 1774, 1718 (br), 1503, 1398, $1072 \mathrm{~cm}^{-1}$. ${ }^{1} \mathrm{H} \mathrm{NMR}(400 \mathrm{MHz}$, $\left.\mathrm{CDCl}_{3}\right) \delta 1.41(3 \mathrm{H}, \mathrm{s}), 2.33(1 \mathrm{H}, \mathrm{m}), 2.46(1 \mathrm{H}, \mathrm{m}), 3.19(1 \mathrm{H}, \mathrm{m}), 3.35(2 \mathrm{H}, \mathrm{m}), 3.48(1 \mathrm{H}, \mathrm{dd}$, $J=8.4,17.1 \mathrm{~Hz}), 3.68(3 \mathrm{H}, \mathrm{s}), 3.74(1 \mathrm{H}, \mathrm{dd}, J=5.1,14.1 \mathrm{~Hz}), 3.88(1 \mathrm{H}, \mathrm{dd}, J=7.0,14.0 \mathrm{~Hz})$, $4.02(1 \mathrm{H}, \mathrm{dd}, J=8.3,14.1 \mathrm{~Hz}), 5.05(1 \mathrm{H}, \mathrm{d}, J=12.3 \mathrm{~Hz}), 5.08(1 \mathrm{H}, \mathrm{d}, J=12.3 \mathrm{~Hz}), 5.42(1 \mathrm{H}$, br s), $7.32(5 \mathrm{H}, \mathrm{m}), 7.72(2 \mathrm{H}, \mathrm{m}), 7.84(2 \mathrm{H}, \mathrm{m}) .{ }^{13} \mathrm{C} \mathrm{NMR}\left(100 \mathrm{MHz}, \mathrm{CDCl}_{3}\right) \delta 22.2,32.9$, 37.2, 42.7 (2 C's), 44.4, 52.4, 57.7, 66.5, 123.4, 127.9, 128.0, 128.4, 131.8, 134.1, 136.3, 154.9, 167.9, 172.0, 175.0. MS (FAB) $m / z 494\left(100 \%, \mathrm{M}+\mathrm{H}^{+}\right)$. Anal. Calcd for

$\mathrm{C}_{26} \mathrm{H}_{27} \mathrm{~N}_{3} \mathrm{O}_{7} \bullet 0.5 \mathrm{H}_{2} \mathrm{O}$ : C 62.1, H 5.6, N 8.4. Found: C 62.4, H 5.7, N 8.1. The second eluting 
diastereomer was obtained as a viscous oil. IR v 3423, 3405, 1775,1718 (br), 1503, 1399, 1075 $\mathrm{cm}^{-1} .{ }^{1} \mathrm{H}$ NMR $\left(400 \mathrm{MHz}, \mathrm{CDCl}_{3}\right) \delta 1.37(3 \mathrm{H}, \mathrm{s}), 2.31(1 \mathrm{H}, \mathrm{m}), 2.43(1 \mathrm{H}, \mathrm{m}), 3.30(2 \mathrm{H}, \mathrm{m})$, $3.45(1 \mathrm{H}, \mathrm{m}), 3.61(2 \mathrm{H}, \mathrm{m}), 3.67(3 \mathrm{H}, \mathrm{s}), 3.87(1 \mathrm{H}, \mathrm{dd}, J=5.1,13.0 \mathrm{~Hz}), 4.00(1 \mathrm{H}, \mathrm{dd}, J=7.5$, $13.0 \mathrm{~Hz}), 5.04(1 \mathrm{H}, \mathrm{d}, J=12.3 \mathrm{~Hz}), 5.05(1 \mathrm{H}, \mathrm{d}, J=12.3 \mathrm{~Hz}), 5.36(1 \mathrm{H}, \mathrm{br} \mathrm{s}), 7.32(5 \mathrm{H}, \mathrm{m})$, $7.71(2 \mathrm{H}, \mathrm{m}), 7.84(2 \mathrm{H}, \mathrm{m}) .{ }^{13} \mathrm{C} \mathrm{NMR}\left(100 \mathrm{MHz}, \mathrm{CDCl}_{3}\right) \delta 22.1,30.8,37.3,42.4,42.8,44.0$, 52.3, 57.7, 66.5, 123.4, 127.9, 128.0, 128.4, 131.8, 134.1, 136.3, 154.9, 167.9, 171.9, 174.9. MS (FAB) $m / z 494\left(100 \%, \mathrm{M}+\mathrm{H}^{+}\right)$.

\section{(3R)-3-Benzyloxycarbonylamino-3-methyl-1-((2RS)-2-methoxycarbonyl-3-phthalimido)- propyl)pyrrolidin-2-thione 38}

To a solution of the lactam 37 (1:1 mixture of diastereomers) (11.6 g, $23.5 \mathrm{mmol})$ in toluene $(250 \mathrm{~mL})$ was added Lawesson's reagent $(5.4 \mathrm{~g}, 13.4 \mathrm{mmol})$. The mixture was refluxed for 1.5 $\mathrm{h}$, then was allowed to cool and the solvent was removed under reduced pressure.

Chromatography of the residue on silica, eluting with 3:2 ethyl acetate/hexanes, gave the dithio compound 39 (1.2 g, 10\%), the starting lactam $37(2.8 \mathrm{~g}, 24 \%)$ and the thiolactam 38 (6.7 $\mathrm{g}$, $56 \%, 74 \%$ based on recovered starting material) as a white foam, as a 1:1 mixture of diastereomers. IR v 3433, 3360, 1774, 1720 (br), 1511, 1496, 1398, $1088 \mathrm{~cm}^{-1}$. ${ }^{1} \mathrm{H}$ NMR (400 $\left.\mathrm{MHz} \mathrm{CDCl}_{3}\right) \delta 1.40(1.5 \mathrm{H}, \mathrm{s}), 1.41(1.5 \mathrm{H}, \mathrm{s}), 2.38(1 \mathrm{H}, \mathrm{m}), 2.55(1 \mathrm{H}, \mathrm{m}), 3.48(0.5 \mathrm{H}, \mathrm{m}), 3.62$ $(2.5 \mathrm{H}, \mathrm{m}), 3.69(1.5 \mathrm{H}, \mathrm{s}), 3.70(1.5 \mathrm{H}, \mathrm{s}), 3.84(1 \mathrm{H}, \mathrm{m}), 3.91(1 \mathrm{H}, \mathrm{m}), 4.03(1.5 \mathrm{H}, \mathrm{m}), 4.40$ $(0.5 \mathrm{H}, \mathrm{m}), 5.05(2 \mathrm{H}, \mathrm{s}), 5.95(0.5 \mathrm{H}$, br s), $6.00(0.5 \mathrm{H}, \mathrm{br} \mathrm{s}), 7.30(5 \mathrm{H}, \mathrm{m}), 7.71(2 \mathrm{H}, \mathrm{m}), 7.83$ $(2 \mathrm{H}, \mathrm{m}) .{ }^{13} \mathrm{C}$ NMR $\left(100 \mathrm{MHz}, \mathrm{CDCl}_{3}\right) \delta 20.8,24.3,24.5,34.2,34.3,37.0,37.2,41.7,47.5$, 47.6, 52.3, 52.6, 66.1, 66.4, 123.2, 127.7, 127.8, 128.2, 131.6, 134.0, 136.2, 154.5, 167.8, 171.8, 204.7. MS (FAB) $m / z 510\left(100 \%, \mathrm{M}+\mathrm{H}^{+}\right)$. Anal. Calcd for $\mathrm{C}_{26} \mathrm{H}_{27} \mathrm{~N}_{3} \mathrm{O}_{6} \mathrm{~S}: \mathrm{C}$ 61.3, H 5.3, N 8.2. Found: C 61.6, H 5.7, N 7.8.

(3R)-3-Benzyloxycarbonylamino-3-methyl-1-((2RS)-3-amino-2-methoxycarbonyl)-propyl) pyrrolidin-2-thione $\mathbf{4 0}$

To a solution of the thiolactam $38(6.44 \mathrm{~g}, 12.7 \mathrm{mmol})$ in dry methanol $(80 \mathrm{~mL})$ was added anhydrous hydrazine (445 $\mathrm{mg}, 13.9 \mathrm{mmol}$ ). The solution was stirred under argon at room temperature for $24 \mathrm{~h}$, after which time a white precipitate had formed. The precipitate was removed by filtration, and the filtrate was concentrated under reduced pressure. The residue was partitioned between methylene chloride and $2 \mathrm{~N} \mathrm{HCl}$. The aqueous layer was made basic ( $\mathrm{pH} 10)$ by the addition of $6 \mathrm{~N} \mathrm{NaOH}$, then was then extracted with methylene chloride. The combined organic phases were dried and the solvent was removed under reduced pressure to give the amine 40 (3.27 g, 68\%) (1:1 mixture of diastereomers) as a pale yellow oil. IR v 3431, 3356, 1717 (br), 1515, 1497, 1443, $1088 \mathrm{~cm}^{-1}$. ${ }^{1} \mathrm{H}$ NMR (400 MHz, $\left.\mathrm{CDCl}_{3}\right) \delta 1.40(1.5 \mathrm{H}, \mathrm{s})$, $1.42(1.5 \mathrm{H}, \mathrm{s}), 1.47(2 \mathrm{H}, \mathrm{br} \mathrm{s}), 2.41(1 \mathrm{H}, \mathrm{m}), 2.52(1 \mathrm{H}, \mathrm{m}), 2.87(0.5 \mathrm{H}, \mathrm{m}), 2.95(1 \mathrm{H}, \mathrm{m}), 3.00$ $(1 \mathrm{H}, \mathrm{m}), 3.09(0.5 \mathrm{H}, \mathrm{m}), 3.63(2 \mathrm{H}, \mathrm{m}), 3.70(1.5 \mathrm{H}, \mathrm{s}), 3.72(1.5 \mathrm{H}, \mathrm{s}), 3.74(0.5 \mathrm{H}, \mathrm{m}), 3.95$ $(0.5 \mathrm{H}, \mathrm{dd}, J=7.6,13.4 \mathrm{~Hz}), 4.06(0.5 \mathrm{H}, \mathrm{m}), 4.25(0.5 \mathrm{H}, \mathrm{dd}, J=6.6,13.4 \mathrm{~Hz}), 5.07(2 \mathrm{H}, \mathrm{s})$, $6.01\left(0.5 \mathrm{H}\right.$, br s), $6.05(0.5 \mathrm{H}, \mathrm{br} \mathrm{s}), 7.33(5 \mathrm{H}, \mathrm{m}) .{ }^{13} \mathrm{C} \mathrm{NMR}\left(100 \mathrm{MHz}, \mathrm{CDCl}_{3}\right) \delta 24.6,34.0$, 34.1, 41.1, 41.2, 45.0, 45.3, 47.3, 47.5, 52.0, 52.1, 52.7, 66.3, 66.5, 66.6, 127.8, 127.9, 128.3, 136.2, 154.6, 173.1, 173.3, 204.4, 204.7. MS (FAB) $m / z 380\left(100 \%, \mathrm{M}+\mathrm{H}^{+}\right)$. HRMS (FAB) $m / z, 380.1650, \mathrm{C}_{18} \mathrm{H}_{26} \mathrm{~N}_{3} \mathrm{O}_{4} \mathrm{~S}$ requires 380.1644 .

(3RS,7S)-7-Benzyloxycarbonylamino-3-methoxycarbonyl-7-methyl-1,5-diazabicyclo[4.3.0] non-5-ene 41

To a solution of the amine $\mathbf{4 0}(1.0 \mathrm{~g}, 2.6 \mathrm{mmol})$ in dioxane $(25 \mathrm{~mL})$ was added mercuric chloride $(1.07 \mathrm{~g}, 3.9 \mathrm{mmol})$. The mixture was stirred at reflux for $24 \mathrm{~h}$, then was allowed to cool to room temperature. The mixture was filtered through celite, washed with acetone, and the filtrate was concentrated under reduced pressure. The residue was purified by chromatography on silica, eluting with a gradient of $\mathrm{CH}_{2} \mathrm{Cl}_{2} / \mathrm{MeOH} /$ isopropylamine (90:10:1-80:20:1), to give the 
bicyclic amidine 41 (567 mg, 62\%) as a colorless oil. Further chromatography enabled isolation of pure samples of each of the diastereomers of amidine 41. The first eluting diastereomer was obtained as a colorless oil: IR $\vee 3408,3275,1738,1717,1692,1508,1310,1275,1089$ $\mathrm{cm}^{-1} .{ }^{1} \mathrm{H}$ NMR $(400 \mathrm{MHz}$, acetone-d 6$) \delta 1.66(3 \mathrm{H}, \mathrm{s}), 2.16(1 \mathrm{H}, \mathrm{ddd}, J=2.9,7.9,12.7 \mathrm{~Hz})$, $2.61(1 \mathrm{H}, \mathrm{ddd}, J=8.8,9.2,12.7 \mathrm{~Hz}), 3.22(1 \mathrm{H}, \mathrm{m}), 3.64(2 \mathrm{H}, \mathrm{m}), 3.70(3 \mathrm{H}, \mathrm{s}), 3.79(4 \mathrm{H}, \mathrm{m})$, $5.06(1 \mathrm{H}, \mathrm{d}, J=12.7 \mathrm{~Hz}), 5.12(1 \mathrm{H}, \mathrm{d}, J=12.7 \mathrm{~Hz}), 7.28(1 \mathrm{H}, \mathrm{m}), 7.35(2 \mathrm{H}, \mathrm{m}), 7.44(2 \mathrm{H}, \mathrm{m})$, $7.74\left(1 \mathrm{H}\right.$, br s). ${ }^{13} \mathrm{C}$ NMR (100 MHz, acetone-d 6 ) $\delta 23.2,32.9,34.2,39.5,44.5,50.7,52.0$, 61.3, 66.0, 127.5, 127.6, 128.3, 137.0, 155.4, 166.2, 170.5. MS (FAB) $m / z 346$ (100\%, M $+\mathrm{H}^{+}$). HRMS (FAB) $m / z$ 346.1773, $\mathrm{C}_{18} \mathrm{H}_{24} \mathrm{~N}_{3} \mathrm{O}_{4}$ requires 346.1767. Anal. Calcd for $\mathrm{C}_{18} \mathrm{H}_{23} \mathrm{~N}_{3} \mathrm{O}_{4} \bullet \mathrm{HCl} \bullet 2 \mathrm{H}_{2} \mathrm{O}$ : C 51.7, H 6.8, N 10.1. Found: C 51.7, H 6.7, N 10.4. The latter eluting diastereomer was obtained as a colorless oil; IR $v 3412$, 3278, 1739, 1717, 1691, 1508, 1311, $1279,1091 \mathrm{~cm}^{-1} .{ }^{1} \mathrm{H}$ NMR $(400 \mathrm{MHz}$, acetone-d 6$) \delta 1.76(3 \mathrm{H}, \mathrm{s}), 2.15(1 \mathrm{H}, \mathrm{ddd}, J=3.3,8.3$, 12.7 Hz), $2.57(1 \mathrm{H}, \mathrm{ddd}, J=7.8,9.3,12.7 \mathrm{~Hz}), 3.42(1 \mathrm{H}, \mathrm{m}), 3.59(2 \mathrm{H}, \mathrm{m}), 3.66(3 \mathrm{H}, \mathrm{s}), 3.75$ $(2 \mathrm{H}, \mathrm{m}), 3.90(2 \mathrm{H}, \mathrm{m}), 5.08(2 \mathrm{H}, \mathrm{m}), 7.28(1 \mathrm{H}, \mathrm{m}), 7.36(2 \mathrm{H}, \mathrm{m}), 7.44(2 \mathrm{H}, \mathrm{m}), 7.72(1 \mathrm{H}, \mathrm{br}$ s). ${ }^{13} \mathrm{C} \mathrm{NMR}\left(100 \mathrm{MHz}\right.$, acetone- $\left.\mathrm{d}_{6}\right) \delta 23.8,32.9,34.6,39.1,44.1,50.7,52.0,61.3,65.8,127.3$, $127.5,128.3,137.0,155.3,166.1,170.0$. MS (FAB) $m / z 346\left(100 \%, \mathrm{M}+\mathrm{H}^{+}\right)$. HRMS (FAB) $m / z 346.1764, \mathrm{C}_{18} \mathrm{H}_{24} \mathrm{~N}_{3} \mathrm{O}_{4}$ requires 346.1767.

\section{(3S,7S)-7-Benzyloxycarbonylamino-3-methoxycarbonyl-3,7-dimethyl-1,5-diazabicyclo [4.3.0]non-5-ene 42}

The amidine 41 (1:1 mixture of diastereomers) (1.0 g, $2.9 \mathrm{mmol})$ was dissolved in dry THF and the solution was cooled to $-78^{\circ} \mathrm{C}$. Lithium hexamethyldisilazide (1.0M in THF, $10.2 \mathrm{~mL}$ ) was added slowly, and the solution was stirred for $2 \mathrm{~h}$, at which time methyl iodide $(1.0 \mathrm{~g}, 7.0$ mmol) was added. The solution was stirred for $3 \mathrm{~h}$ at $-78{ }^{\circ} \mathrm{C}$, then was allowed to warm to ca. $0{ }^{\circ} \mathrm{C}$ and was stirred for $1 \mathrm{~h}$. The solution was cooled to $-78{ }^{\circ} \mathrm{C}$ and a further 2 equivalents of LHMDS was added $(5.8 \mathrm{~mL})$, and stirring was continued for $30 \mathrm{~min}$. Methyl iodide (1 eq., $185 \mu \mathrm{L}$ ) was added and the solution was stirred at $-78^{\circ} \mathrm{C}$ for $3 \mathrm{~h}$. The solution was then allowed to warm to ambient temperature overnight. Methanol $(\mathrm{ca} .50 \mathrm{~mL})$ was added to quench the reaction and the solution was evaporated to dryness under reduced pressure. The crude product was purified by chromatography on silica, eluting with $\mathrm{CH}_{2} \mathrm{Cl}_{2} / \mathrm{MeOH} /$ isopropylamine (80:20:1) to give the product $\mathbf{4 2}$ (487 $\mathrm{mg}, \mathbf{4 7 \%}$ ) as a colorless oil. IR $v 3395,3293,1738,1717$, 1690, 1538, 1375, 1261, 1219, $1090 \mathrm{cn}^{-1.1} \mathrm{H}$ NMR (400 MHz, $\left.\mathrm{CDCl}_{3}\right) \delta 1.27(3 \mathrm{H}, \mathrm{s}), 1.65$ $(3 \mathrm{H}, \mathrm{s}), 2.08(1 \mathrm{H}, \mathrm{m}), 2.62(1 \mathrm{H}, \mathrm{m}), 3.11(1 \mathrm{H}, \mathrm{d}, J=13 \mathrm{~Hz}), 3.29(1 \mathrm{H}, \mathrm{d}, J=13 \mathrm{~Hz}), 3.58-$ $3.87(4 \mathrm{H}, \mathrm{m}), 3.64(3 \mathrm{H}, \mathrm{s}), 5.05(2 \mathrm{H}, \mathrm{m}), 7.28(5 \mathrm{H}, \mathrm{m}), 7.35(1 \mathrm{H}, \mathrm{br} \mathrm{s}) .{ }^{13} \mathrm{C} \mathrm{NMR}(100 \mathrm{MHz}$, $\left.\mathrm{CDCl}_{3}\right) \delta 20.7,24.3,30.8,32.9,38.9,46.6,50.3,52.8,60.4,66.1,127.1,127.6,128.3,136.5$, 156.0, 166.2, 172.9. MS (FAB) $m / z 360\left(100 \%, \mathrm{M}+\mathrm{H}^{+}\right)$. HRMS (FAB) $m / z$ 360.1915, $\mathrm{C}_{19} \mathrm{H}_{26} \mathrm{~N}_{3} \mathrm{O}_{4}$ requires 360.1923 .

\section{(3S,7S)-7-Benzyloxycarbonylamino-3-carboxy-3,7-dimethyl-1,5-diazabicyclo[4.3.0]non-5- ene 43}

The amidine ester 42 (300 mg, $0.84 \mathrm{mmol})$ was dissolved in 1:1:1 THF:MeOH:1.0M $\mathrm{LiOH}_{\mathrm{aq}}(5 \mathrm{~mL})$. The solution was stirred at room temperature $18 \mathrm{~h}$, and lyophilized to give a white foam. The residue was taken up in methanol $(5 \mathrm{~mL})$ and $3 \mathrm{~N} \mathrm{HCl}(c a .0 .3 \mathrm{~mL})$ was added to lower the $\mathrm{pH}$ to 6 . The mixture was filtered and the filtrate was evaporated under reduced pressure to give the acid $43(288 \mathrm{mg}, 100 \%)$ as a white solid. ${ }^{1} \mathrm{H} \mathrm{NMR}(400 \mathrm{MHz}, \mathrm{MeOH}-$ $\left.\mathrm{d}_{4}\right) \delta 1.20(3 \mathrm{H}, \mathrm{s}), 1.56(3 \mathrm{H}, \mathrm{s}), 2.17(1 \mathrm{H}, \mathrm{m}), 2.58(1 \mathrm{H}, \mathrm{m}), 3.24(2 \mathrm{H}, \mathrm{m}), 3.53(1 \mathrm{H}, \mathrm{m}), 3.75$ $(3 \mathrm{H}, \mathrm{s}), 5.09(2 \mathrm{H}, \mathrm{s}), 7.36(5 \mathrm{H}, \mathrm{m}) .{ }^{13} \mathrm{C} \mathrm{NMR}\left(100 \mathrm{MHz}, \mathrm{MeOH}-\mathrm{d}_{4}\right) \delta 20.1,22.5,32.7,39.1$, 46.0, 50.1, 50.9, 60.7, 66.4, 127.5, 127.7, 128.1, 155.6, 165.4, 177.2. MS (FAB) $m / z .368$ (8\%, $\left.\mathrm{M}+\mathrm{Na}^{+}\right), 352\left(38, \mathrm{M}+\mathrm{Li}^{+}\right), 346\left(44, \mathrm{M}+\mathrm{H}^{+}\right), 313$ (100). HRMS (FAB) $m / z$ 346.1773, $\mathrm{C}_{18} \mathrm{H}_{24} \mathrm{~N}_{3} \mathrm{O}_{4}$ requires 346.1767 . 
(3S,7S)-7-Benzyloxycarbonylamino-3-tert-butoxycarbonylamino-3,7-dimethyl-1,5diazabicyclo[4.3.0]non-5-ene Diphenylphosphate 44

To a solution of the acid $\mathbf{4 3}(100 \mathrm{mg}, 0.29 \mathrm{mmol})$ in dry t-butanol/acetonitrile $(2: 1,4.5 \mathrm{~mL})$ in a screw-capped pressure bottle was added DPPA $(112 \mathrm{mg}, 0.41 \mathrm{mmol})$ and triethylamine (32 $\mathrm{mg}, 0.32 \mathrm{mmol})$. The bottle was flushed with argon before affixing the cap, then was placed in a sand bath at $c a .110^{\circ}$. The solution was heated for $36 \mathrm{~h}$, then was allowed to cool. Ether $(8 \mathrm{~mL})$ was added and the solution was stored at $4^{\circ}$ overnight. The precipitate (diphenyl phosphate) was removed by filtration, the solid was washed with ether, and the filtrate was evaporated under reduced pressure. The residue was purified by chromotography on silica to give the amidine diphenyl phosphate salt $44(84 \mathrm{mg}, 45 \%) .{ }^{1} \mathrm{H}$ NMR $\left(400 \mathrm{MHz}, \mathrm{MeOH}-\mathrm{d}_{4}\right) \delta$ $1.41(3 \mathrm{H}, \mathrm{s}), 1.43(9 \mathrm{H}, \mathrm{s}), 1.52(3 \mathrm{H}, \mathrm{s}), 2.15(1 \mathrm{H}, \mathrm{ddd}, J=3.5,7.0,12.7 \mathrm{~Hz}), 2.59(1 \mathrm{H}, \mathrm{m})$, $3.16(1 \mathrm{H}, \mathrm{d}, J=13 \mathrm{~Hz}), 3.35(1 \mathrm{H}, \mathrm{d}, J=13 \mathrm{~Hz}), 3.73(2 \mathrm{H}, \mathrm{m}), 3.79(1 \mathrm{H}, \mathrm{d}, J=13 \mathrm{~Hz}), 3.89$ $(1 \mathrm{H}, \mathrm{d}, J=13 \mathrm{~Hz}), 5.07(1 \mathrm{H}, \mathrm{d}, J=12.4 \mathrm{~Hz}), 5.14(1 \mathrm{H}, \mathrm{d}, J=12.4 \mathrm{~Hz}), 7.34(5 \mathrm{H}, \mathrm{m}) ;{ }^{13} \mathrm{C}$ $\operatorname{NMR}\left(100 \mathrm{MHz}, \mathrm{CDCl}_{3}\right) \delta 21.3,24.6,28.2,31.7,33.3,45.8,51.2,53.8,60.8,66.6,79.7$, $120.3^{*}, 120.3^{*}, 122.9^{*}, 127.7,128.3,129.0,136.4,153.1^{*}, 155.0,156.2,166.7,[*=$ $(\mathrm{PhO})_{2} \mathrm{PO}_{2}{ }^{-}$]; MS (FAB) $\mathrm{m} / z 417\left(100 \%, \mathrm{M}+\mathrm{H}^{+}\right)$. HRMS (FAB) $\mathrm{m} / z$ 417.2512, $\mathrm{C}_{22} \mathrm{H}_{33} \mathrm{~N}_{4} \mathrm{O}_{4}$ requires 417.2502 .

\section{Supplementary Material}

Refer to Web version on PubMed Central for supplementary material.

\section{Acknowledgements}

This work was supported by National Institutes of Health (USA) grant GM-28965.

\section{References}

1. Freidinger RM. J Med Chem 2003;46:5553-5566. [PubMed: 14667208]

2. Cluzeau J, Lubell WD. Biopolymers (Pept Sci) 2005;80:98-150.

3. Souers AJ, Ellman JA. Tetrahedron 2001;57:7431-7448.

4. Hanessian S, McNaughton-Smith G, Lombart HG, Lubell WD. Tetrahedron 1997;53:12789-12854.

5. Eguchi M, Kahn M. Mini Rev Med Chem 2002;2:447-462. [PubMed: 12370046]

6. d 1 Figuera N, Martin-Martinez M, Herranz R, Garcia-Lopez MT, Latorre M, Cenarruzabeitia E, d Rio J, Gonzalez-Muniz R. Bioorg Med Chem Lett 1999;9:43-48. [PubMed: 9990454]

7. Wang W, Xiong C, Hruby VJ. Tetrahedron Lett 2001;42:3159-3161.

8. Kim HO, Nakanishi H, Lee MS, Kahn M. Org Lett 2000;2:301-302. [PubMed: 10814307]

9. Virgilio AA, Ellman JA. J Am Chem Soc 1994;116:11580-11581.

10. Virgilio AA, Schurer SC, Ellman JA. Tetrahedron Lett 1996;37:6961-6964.

11. Hinds MG, Richards NGJ, Robinson JA. J Chem Soc, Chem Commun 1988:1447-1449.

12. Golebiowski A, Jozwik J, Klopfenstein SR, Colson AO, Grieb AL, Russell AF, Rastogi VL, Diven CF, Portlock DE, Chen JJ. J Comb Chem 2002;4:584-590. [PubMed: 12425603]

13. Golebiowski A, Klopfenstein SR, Chen JJ, Shao X. Tetrahedron Lett 2000;41:4841-4844.

14. Zhang J, Xiong C, Ying J, Wang W, Hruby VJ. Org Lett 2003;5:3115-3118. [PubMed: 12916995]

15. Eguchi M, Lee MS, Nakanishi H, Stasiak M, Lovell S, Kahn M. J Am Chem Soc 1999;121:1220412205.

16. Gutierrez-Rodriguez M, Garcia-Lopez MT, Herranz R. Tetrahedron 2004;60:5177-5183.

17. Blomberg D, Hedenstrom M, Kreye P, Sethson I, Brickmann K, Kihlberg J. J Org Chem 2004;69:3500-3508. [PubMed: 15132562]

18. Brickmann K, Yuan Z, Sethson I, Somfai P, Kihlberg J. Chem Eur J 1999;5:2241-2253.

19. Baeza JL, Gerona-Navarro G, d Vega JP, Garcia-Lopez T, Gonzalez-Muniz R, Martin-Martinez M. Tetrahedron Lett 2007;48:3689-3693. 
20. Herrero S, Garcia-Lopez MT, Latorre M, Cenarruzabeitia E, Rio JD, Herranz R. J Org Chem 2002;67:3866-3873. [PubMed: 12027705]

21. Hammond MC, Bartlett PA. J Org Chem 2007;72:3104-3107. [PubMed: 17371075]

22. Phillips ST, Blasdel LK, Bartlett PA. J Am Chem Soc 2005;127:4193-4198. [PubMed: 15783200]

23. Boatman PD, Ogbu CO, Eguchi M, Kim HO, Nakanishi H, Cao B, Shea JP, Kahn M. J Med Chem 1999;42:1367-1375. [PubMed: 10212122]

24. Chandrasekhar S, Babu BN, Prabhakar A, Sudhakar A, Reddy MS, Kiran MU, Jagadeesh B. Chem Commun 2006:1548-1550.

25. Loughlin WA, Tyndall JDA, Glenn MP, Fairlie DP. Chem Rev 2004;104:6085-6117. [PubMed: 15584696]

26. Reid RC, Pattenden LK, Tyndall JDA, Martin JL, Walsh T, Fairlie DP. J Med Chem 2004;47:16411651. [PubMed: 15027855]

27. Austin RE, Maplestone RA, Sefler AM, Liu K, Hruzewicz WN, Liu CW, Cho HS, Wemmer DE, Bartlett PA. J Am Chem Soc 1997;119:6461-6472.

28. Kemp DS, Allen TJ, Oslick SL, Boyd JG. J Am Chem Soc 1996;118:4240-4248.

29. Maison W, Arce E, Renold P, Kennedy RJ, Kemp DS. J Am Chem Soc 2001;123:10245-10254. [PubMed: 11603974]

30. Davis JM, Tsou LK, Hamilton AD. Chem Soc Rev 2007;36:326-334. [PubMed: 17264933]

31. Horwell DC, Howson W, Ratcliffe GS, Willems HMG. Bioorg Med Chem 1996;4:33-42. [PubMed: 8689236]

32. Nagai U, Sato K, Nakamura R, Kato R. Tetrahedron 1993;49:3577-3592.

33. Ternansky RJ, Draheim SE. Tetrahedron 1992;48:777-796.

34. Bock MG, DiPardo RM, Evans BE, Rittle KE, Freidinger RM, Chang RSL, Lottit VJ. J Med Chem 1988;31:268-271. [PubMed: 2826786]

35. Oediger H, Moller F, Eiter K. Synthesis 1972;11:591-598.

36. Shrader WD, Marlowe CK. Bioorg Med Chem Lett 1995;5:2207-2210.

37. Karady S, Amato JS, Weinstock LM. Tetrahedron Lett 1984;25:4337-4340.

38. Scheibye S, Pedersen BS, Lawesson SO. Bull Soc Chim Belg 1978;87:229-238.

39. Foloppe MB, Rault S, Robba* M. Tetrahedron Lett 1992;33:2803-2804.

40. Dunstan S, Henbest HB. J Chem Soc 1957:4905-4908.

41. Baker SR, Parsons AF, Wilson M. Tetrahedron Lett 1998;39:331-332.

42. Laurent M, Ceresiat M, Marchand-Brynaert J. Eur J Org Chem 2006:3755-3766.

43. Carpino LA, Padykula RE, Barr DE, Hall FH, Krause JG, Dufresne RF, Thoman CJ. J Org Chem 1988;53:2565-2572.

44. Christoforou IC, Koutentis PA. Org Biomol Chem 2006;4:3681-3693. [PubMed: 16990945]

45. Rebek J Jr, Askew B, Killoran M, Nemeth D, Lin FT. J Am Chem Soc 1987;109:2426-2431.

46. Sibi MP, Patil K. Angew Chem Int Ed 2004;43:1235-1238.

J Org Chem. Author manuscript; available in PMC 2008 September 2. 


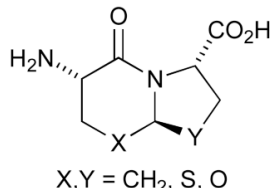

1

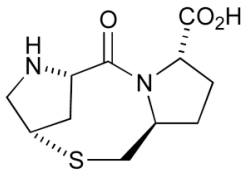

5
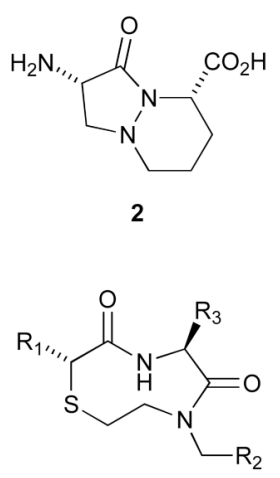

6<smiles>[R6]C(C(=O)O)N1C[C@H]2C(=O)N[C@@H]([R8])C(=O)N2C([R6])C1=O</smiles>

3

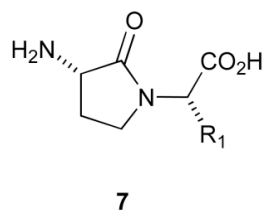<smiles>CC1(C(=O)O)CC(=O)C2=C(C1)NCC2C=O</smiles>

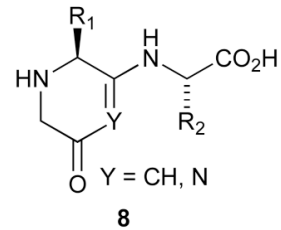

Figure 1.

Cyclic small molecule peptidomimetic scaffolds 


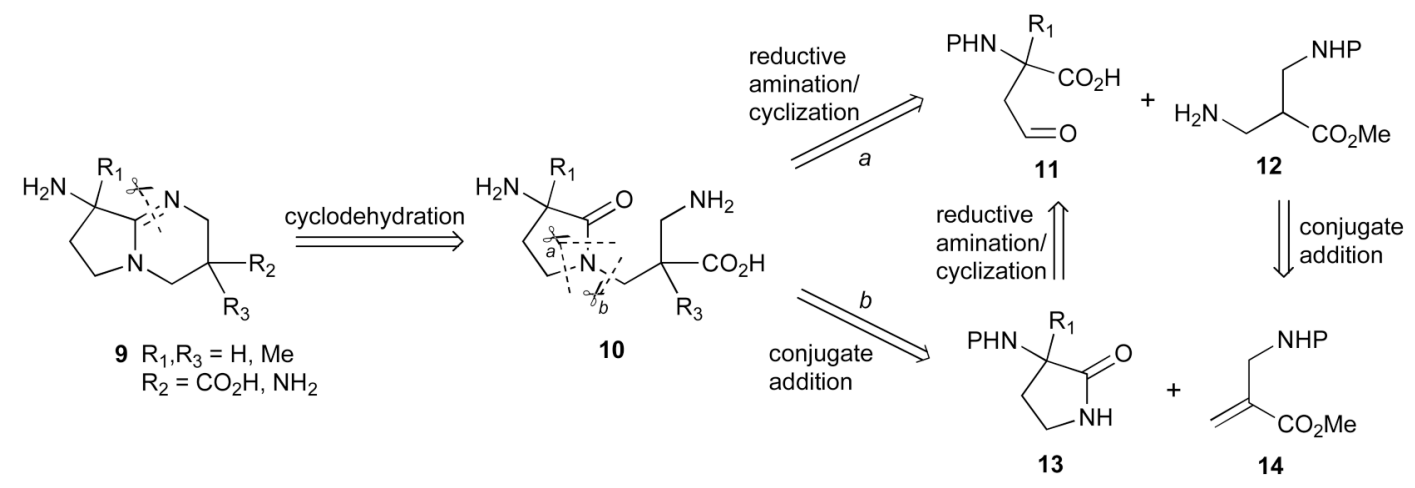

Scheme 1. 


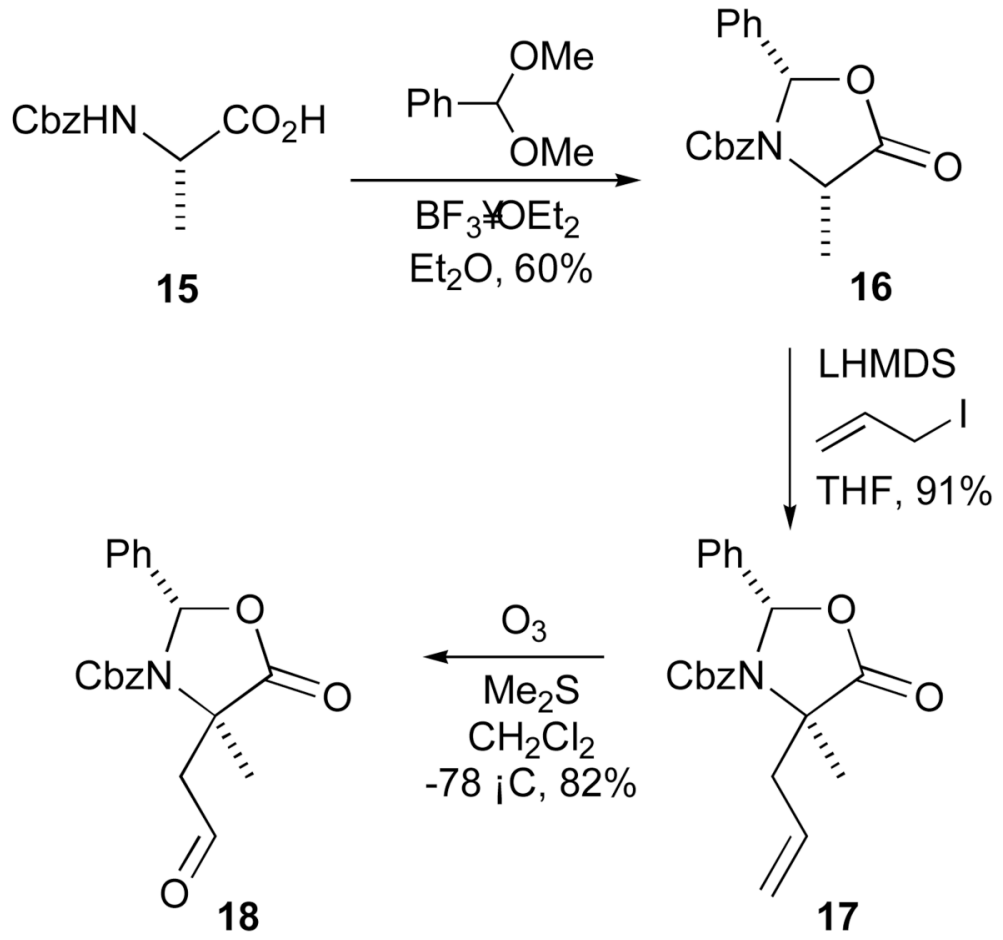

Scheme 2. 

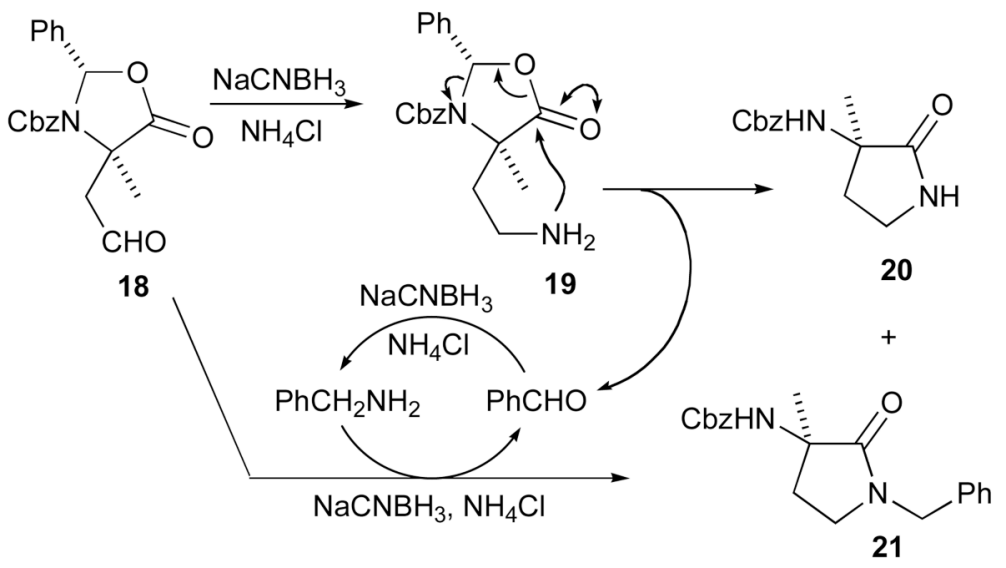

Scheme 3. 


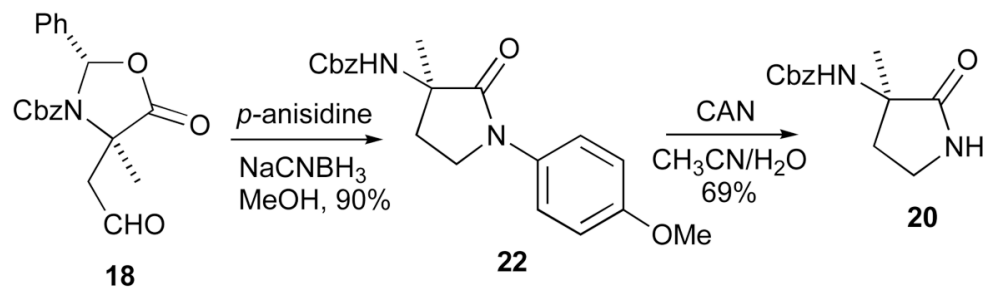

Scheme 4. 


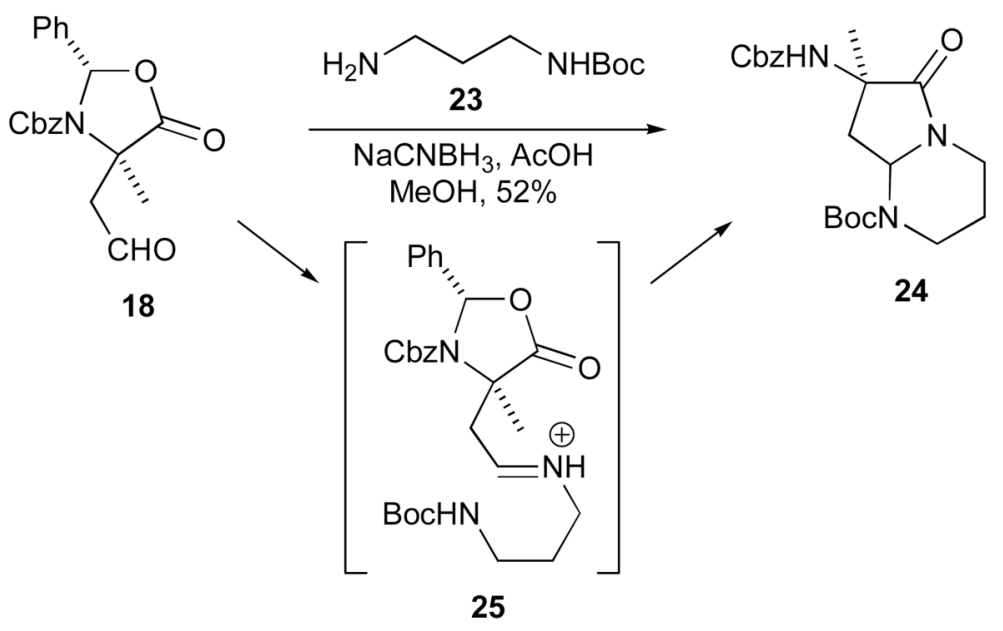

Scheme 5. 


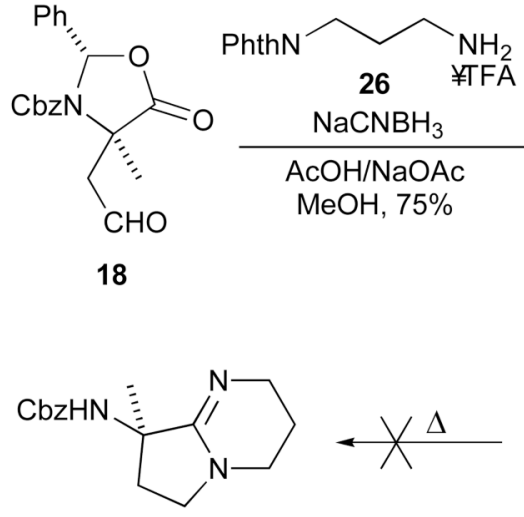

29

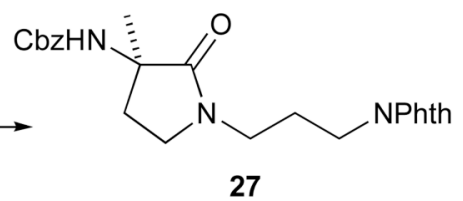

$\mathrm{NH}_{2} \mathrm{NH}_{2} ¥ \mathrm{H}_{2} \mathrm{O}$ $\mathrm{EtOH}, \Delta, 77 \%$

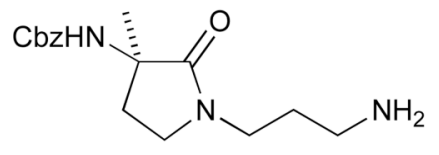

28

Scheme 6. 


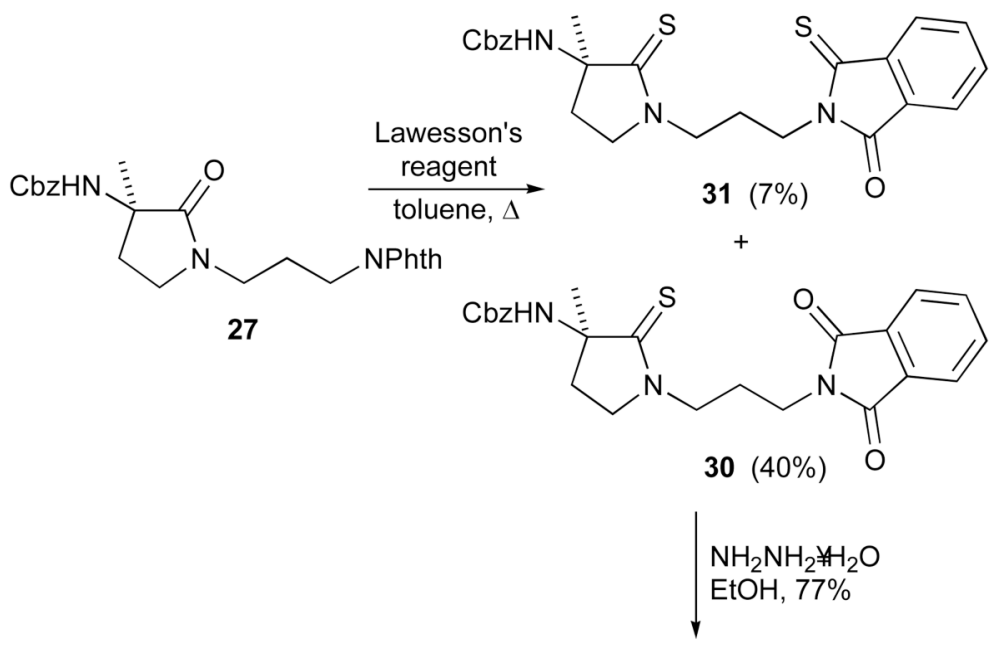

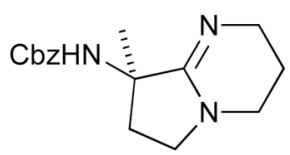

29

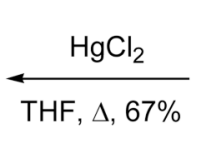

THF, $\Delta, 67 \%$

32

Scheme 7. 
<smiles>C=C(CBr)C(C)=O</smiles>

33

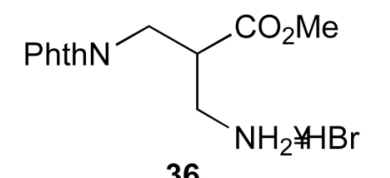

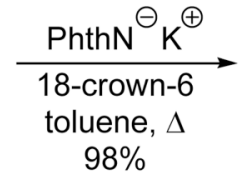

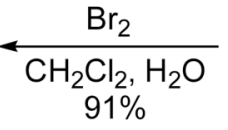

$91 \%$<smiles>C=C(CNc1ccccc1)C(C)=O</smiles>

34

$\mid \begin{aligned} & \mathrm{BnNH}_{2} \\ & \mathrm{CHCl}_{3}, \Delta \\ & 57 \%\end{aligned}$<smiles>CC(=O)C(CNc1ccccc1)CNc1ccccc1</smiles>

35

Scheme 8 . 


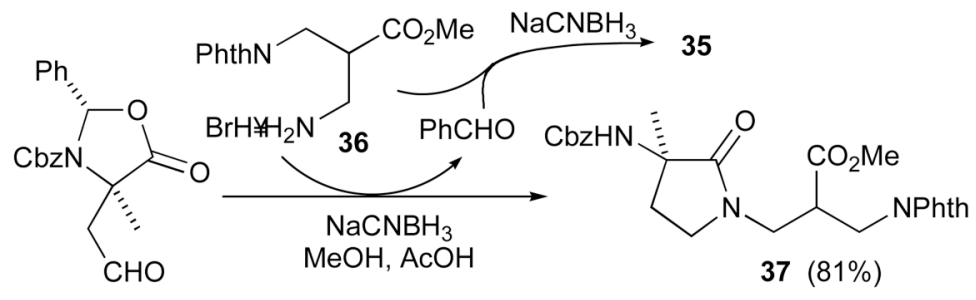

18
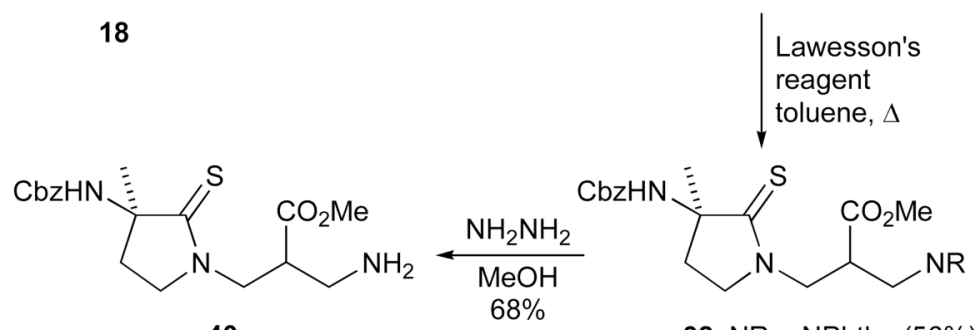

40
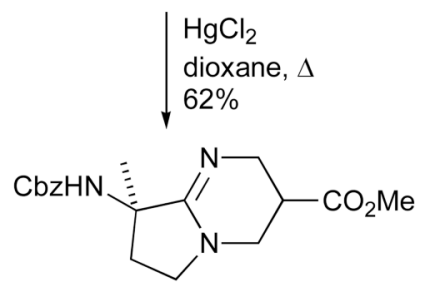

41
38 NR $=$ NPhth $(56 \%)$

$39 \mathrm{NR}=\mathrm{O}_{(10 \%)}$

Scheme 9. 
<smiles>CCCCOC(=O)N[C@@]1(C)CCN2CC(C(=O)OC)CN=C21</smiles>

41

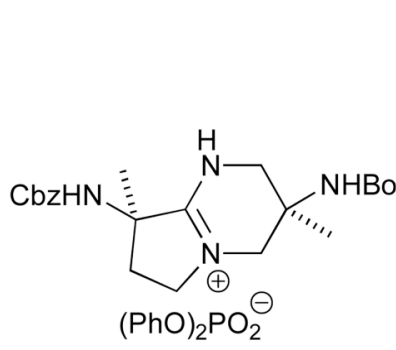

44

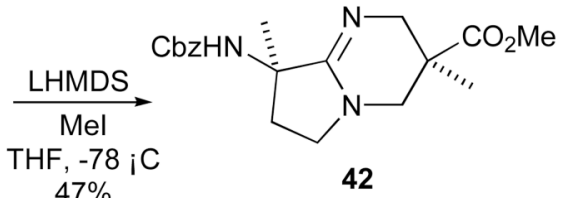

$\mathrm{LiOH}$

THF, $\mathrm{MeOH}, \mathrm{H}_{2} \mathrm{O}$ $\downarrow$ quant.

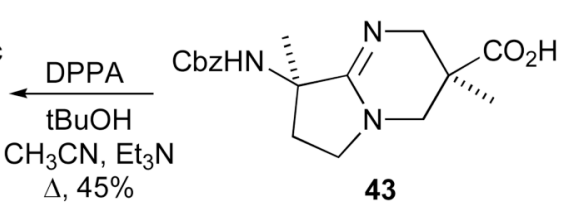

Scheme 10. 